\title{
Editorial
}

\section{Site-Specific Nutrient Management}

\author{
Witold Grzebisz $\mathbb{D}$
}

Citation: Grzebisz, W. Site-Specific Nutrient Management. Agronomy 2021, 11, 752. https://doi.org/ 10.3390/agronomy11040752

Received: 17 March 2021

Accepted: 8 April 2021

Published: 13 April 2021

Publisher's Note: MDPI stays neutral with regard to jurisdictional claims in published maps and institutional affiliations.

Copyright: (C) 2021 by the author. Licensee MDPI, Basel, Switzerland. This article is an open access article distributed under the terms and conditions of the Creative Commons Attribution (CC BY) license (https:// creativecommons.org/licenses/by/ $4.0 /)$.
Department of Agricultural Chemistry and Environmental Biogeochemistry, Poznan University of Life Sciences, Wojska Polskiego 28, 60-637 Poznan, Poland; witold.grzebisz@up.poznan.pl; Tel.: +48-618-487-788

\begin{abstract}
The editorial introduces to a Special Issue entitled "Site-Specific Nutrient Management. The concept of the nitrogen gap (NG) is as a core challenge for an effective realization of the so called "twin objectives" in sustainable agriculture. This special issue stresses on some hot spots in crop production, being responsible in the yield gap development, that farmers have to take control. The yield gap cannot be ameliorated without the synchronization of the in-season requirements of the currently grown crop for $\mathrm{N}$ with its three-dimensional variability in a supply on a field (temporal, spatial and vertical). A recognition of soil fertility status in the rooted zone, which includes availability of both mineral $\mathrm{N}$ and nutrients decisive for its uptake, is the first step in the NG amelioration. The sustainability in soil fertility, as a prerequisite of $\mathrm{N}$ fertilizer application, requires a wise strategy of organic matter management, based on farmyard manure, and/or cultivation of legumes. The soil fertility status, irrespectively of the World region determines ways of the $\mathrm{N}$ rate optimization. The division of a particular field into homogenous productive units is the primary step in the NG cover. It can be delineated, using both data on soil physico-chemical properties of the soil rooted zone, and then validated by using satellite spectral images of the crop biomass in a well-defined stage of its growth, decisive for yield. The proposed set of diagnostic tools is a basis for elaboration an effective agronomic decision support system.
\end{abstract}

Keywords: a field; crop production; sustainability; homogenous productivity units; soil fertility; nitrogen indicators: in-season; spatial; vertical variability of N demand and supply; spectral imagery; vegetation indices

\section{Introduction: On a Way to Reach Sustainability in Crop Production}

The effective realization of the 'twin objectives' of the concept of sustainable agriculture assumes efficient food production and the simultaneous protection of both the local and global ecosystem. This concept is based on the optimization of the applied production inputs [1]. In crop production, the efficient use of inputs is defined by the size of the yield gap (YG), which results from inefficiency in the use of $\mathrm{N}$ fertilizer $\left(\mathrm{N}_{\mathrm{f}}\right)$ under well-defined soil and weather conditions [2,3]. The full recognition of the production factors allows the climatic-yield potential (CYP) of the currently grown plant and its seasonal variability to be determined [4]. The size of the existing YG, considered as the deviation from the CYP, is the basis for the elaboration of an agronomic decision support system oriented towards its cover. In rain-fed agriculture, the first step towards YG cover is to increase the resistance of a grown plant to in-season weather variability. This action, as a rule, focuses on improvement in water management [5]. The key, and in fact the long-term strategy, of water management control should be oriented to soil fertility improvement (organic matter content, soil $\mathrm{pH}$ ). This is required in order to decrease the yield variability. The efficient use of both indigenous fertilizer and $\mathrm{N}_{\mathrm{f}}$ requires efforts that concentrate on the optimization of both the $\mathrm{N}_{\mathrm{f}}$ rate and the factors responsible for its uptake and utilization by the currently-grown plant. Solving these challenges requires well-elaborated diagnostic methods which take into account both classical chemometric and remote-sensing tools [2]. 


\section{Special Issue Overview: General Topics}

\subsection{In-Season Management of Nitrogen: A Challenge for the Present Generation}

The first chapter of the Special Issue comprises two papers which focus the reader's attention on $\mathrm{N}$ management within a particular field, as a basic production unit $[2,6]$. Nitrogen, under conditions of ample water supply, is the main production factor. It affects growth and the exploitation of the yield potential of the currently-grown plant. This first temporal (in-season) variability is defined by a crop's requirement for $\mathrm{N}$, and can be taken under control, provided there is a recognition of the crop's critical stages of yield formation. In the case of seed crops, the game for yield takes place during the linear period of a crop's biomass increase. For cereals, it covers the phase of stem elongation [7]. In spite of the in-season variability of the seed crop requirements for $\mathrm{N}$, the yield for a particular field depends to a considerable degree on the factors which are responsible for its spatial variability. Hence, the main challenge for a farmer is to divide the whole field area into homogenous field productive units, HFPUs [8]. Spectral imagery is a useful tool to recognize the plants' nutritional status within a growing season. Its advantage over classical biometric methods is the quick determination and simultaneous discrimination of the difference in the rate of a crop biomass increase between HFPUs [9]. However, the accurate discrimination of a given HFPU boundary requires strict data on the soil's physical and chemometric characteristics which are decisive for water and nutrient content in the whole rooted soil zone [10].

The sound management of $\mathrm{N}$, both indigenous to the soil and applied as $\mathrm{N}_{\mathrm{f}}$, relies on simultaneously maximizing yield and minimizing the negative impact of the $\mathrm{N}$ present in the soil/plant continuum of the environment. A basic set of operationally-required data comprises: (i) the $\mathrm{N}$ productivity in a particular HFPU, (ii) the size of the pool of mineral nitrogen $\left(\mathrm{N}_{\min }\right)$ at the onset of the growing season or at a time of winter crop regrowth in spring, (iii) the total amount of applied $N_{f}$, and (iv) the in-season division of the whole $N_{f}$ rate. The reliable indicators of the in-season $\mathrm{N}$ management are strongly correlated with $\mathrm{N}$ released from its organic pool during the growing season. This assumption, resulting from the study by Łukowiak at al. [6], can be fulfilled by using the N-balance $\left(\mathrm{N}_{\mathrm{b}}\right)$ as the $\mathrm{N}$ management indicator. This only seemingly-simple index is based on the $\mathrm{N}$ input into the soil/crop system $\left(\mathrm{N}_{\mathrm{in}}=\mathrm{N}_{\min }+\mathrm{N}_{\mathrm{f}}\right)$ and the total $\mathrm{N}$ content in a crop plant at harvest (TN). It allows the discrimination of HFPUs differing significantly in productivity, and consequently defines the requirement of a crop for $\mathrm{N}_{\mathrm{f}}$. Its practical advantage is to calibrate the variability in the $\mathrm{N}_{\mathrm{f}}$ rate between neighboring HFPUs.

\subsection{Soil Fertility Management/Improvement}

The second chapter is devoted to the aspects of soil fertility management that can ensure a high efficiency of the applied production measures [10-12]. Sustainability in the crop production system is based on the stabilization of the nutrient supply to plants within a particular crop rotation. Sugar beet, in temperate climatic regions, is the most sensitive crop to the soil fertility level, which is decisive for the sugar yield [13]. The expected stabilization in the nutrient supply to this crop is mainly achieved through manure application, which is a source of both organic matter and nutrients. Sugar beet, as reported by Hlisnikovsky et al. [12], very efficiently exploits the applied $\mathrm{N}_{\mathrm{f}}$ under conditions of simultaneous manure and NPK application. The high efficiency of $\mathrm{N}_{\mathrm{f}}$ is mainly due to the increase in the content of the soil's available nutrients. In the studied case, it referred to $\mathrm{P}$ and $\mathrm{K}$. A high sugar yield was obtained in treatments with a much lower input of mineral fertilizers (FYM + NPK2 vs. NPK4). A synergy between the effects of mineral fertilizers and manure is especially important in unfavorable weather conditions, for example drought.

A sustainable system of crop production should be based on legume crops, grown at least once in a crop rotation. The impact of these plants on soil fertility is well recognized, but is also frequently neglected in intensive farming systems [14]. The yield production functions of legumes, in the light of $\mathrm{N}_{2}$ fixation, is out of discussion. However, farmers tend to overlook some other functions of legumes which are responsible for both the soil's 
fertility build-up and its long-term stabilization. The rhizodeposition of carbon by roots to the soil leads to an enormous increase in the activity of microorganisms. The in-season dynamics of $\mathrm{C}$ and $\mathrm{N}$ rhizodeposition are related to the stage of legume crop growth, reaching their maximum at the onset of flowering [15]. The increased activity of enzymes produced by both plants and microbes achieves its maximum just at the stage of the legume plant's flowering. The acid phosphatase (PAC) is an important factor, impacting the supply of phosphorus to plants [11]. The majority of the nutrients released from soil resources, especially $\mathrm{N}$ and $\mathrm{P}$, are taken up by a legume plant during the phases of seed growth. The remaining portion increases the soil fertility level and become available to the succeeding crop [14].

The in-season dynamics of the nutrient uptake by a plant, especially of $\mathrm{N}_{\min }$, are a key factor affecting both (i) the rate of the crop plant growth, (ii) the formation of the yield components. As in the case of legumes, seed crops are also sensitive to the supply of nutrients during this period of yield component formation. In winter oilseed rape, the yield is significantly related to the nitrate nitrogen $(\mathrm{NN})$ supply during the period extending from the rosette up to flowering [10]. The shortage of the $\mathrm{N}$ supply to plants at this time results in a significant yield decline. The supply of NN, as reported by Grzebisz et al. [10], depended not only on the amount of $\mathrm{N}_{\mathrm{f}}$ applied to the crop, but also on the availability of other nutrients which are responsible for the NN uptake from the soil. In sandy soils, the most constraining nutrients for Winter Oilseed Rape (WOSR) growth and yield are potassium $(\mathrm{K})$, magnesium $(\mathrm{Mg})$, and calcium $(\mathrm{Ca})$. The limiting effect of $\mathrm{K}$ on $\mathrm{N}$ uptake by plants, as the nutrient taken-up by WOSR in the highest amounts, persists through the entire growth of WOSR plants $[10,16]$.

\subsection{Site-Specific Response of Crop Plants to Soil Fertility and Management}

The yield variability between cropped fields is affected by different factors. The main reasons for the observed variabilities not only result from differences in soil characteristics (soil type, agronomy class) but also from the field cropping history, or the current crop management. Such variability is discussed in this chapter.

The soil type is the key factor affecting yields of high-yielding crops, like winter wheat, as was clearly documented by Hlisnikovsky et al. [17]. The principle cause of huge differences in yields cannot only be attributed to the content of the main soil fertility indicators, like the total $\mathrm{N}$ content $\left(\mathrm{N}_{\mathrm{t}}\right)$. It is also worth taking into consideration the content of the available $\mathrm{P}, \mathrm{K}$, and $\mathrm{Mg}$, as well as $\mathrm{Ca}$. The stabilization impact of FYM application has been revealed as an important factor, both in the Chernozem and in Cambisol, as documented by the authors. The advantage of naturally-fertile soils like Chernozem and Phaeozem is the much lower rate of $\mathrm{N}$ required to achieve the maximum yield of wheat. In the case of Cambisol, the same yield can be also obtained provided there is an application a significantly higher $\mathrm{N}_{\mathrm{f}}$ rate. In contrast, the quality of the wheat grain requires an extra $\mathrm{N}_{\mathrm{f}}$ dose, irrespective of the achieved yield. It can therefore be concluded that the $\mathrm{N}_{\mathrm{f}}$ efficiency in wheat depends on the soil fertility level, but the grain quality is driven solely by the $\mathrm{N}_{\mathrm{f}}$ rate.

The same problem, but related to maize, was discussed in the paper by Wang et al. [18]. The used index of $\mathrm{N}$ efficiency, i.e., the economic optimal $\mathrm{N}$ rate (EONR), in combination with the soil type, the course of the weather, and plant density, can be used as an advisory tool oriented towards increasing the efficiency of $\mathrm{N}_{\mathrm{f}}$. The year-to-year variability in yield trends, irrespective of the weather course in a particular growing season, was completely different for Black Earth and Aeolian sandy soil. As a rule, the yields of maize grown on Black Earth increased in response to an increased $N_{f}$ rate in accordance with the Mitscherlich law. The trend of the maize yield grown on Aelioan sandy soil followed the linear-plateau model, showing a significant seasonal variability. The comparison of the EONR values clearly stresses the differences between soil types. The importance of other factors, leading to the increased efficiency of the applied Nf with respect to farmers' practices was significant, but at a much lower level. The Partial Factor Productivity of N 
fertilizer $\left(\mathrm{PFP}_{\mathrm{Nf}}\right)$ was revealed as a good indicator, reflecting differences in the effects of maize production factors.

The yield of a seed crop is defined by two primary components, i.e., the seed density per unit soil area (SD) and the seed weight (1000 seed/grain weight, TSW/TGW). The effect of $\mathrm{N}$ application on WOSR depends on both (i) SD, which is established during inflorescence development and fixed during the phase of pod growth, and (ii) TSW, which is established during the stages of pod formation and seed maturation [19]. The study by Łukowiak and Grzebisz et al. [20] on WOSR clearly showed that yield was significantly affected by the N content of seeds $\left(\mathrm{N}_{\mathrm{se}}\right)$. This seed characteristic was a decisive factor for seed survival during the post-anthesis WOSR growth, being responsible for SD. In addition, $\mathrm{N}_{\text {se }}$ was positively related to $\mathrm{PFP}_{\mathrm{Nf160}}$. It was found to be a criterion for the differing of the investigated fields with respect to yield in a particular year. An efficient $\mathrm{N}$ management strategy requires data on the $\mathrm{N}_{\min }$ content at the onset of the growing season [21]. The interaction between a season and the field location allowed two strategies of $\mathrm{N}_{\mathrm{f}}$ management to be distinguished, both of which were oriented towards SD maximization. The first strategy was based on current soil productivity. The second one was based on indigenous soil fertility. Both strategies resulted in a high SD as the prerequisite of a high seed/grain yield. This observation was also corroborated by the main conclusion, drawn from the study with wheat and maize discussed in chapter 2.

\subsection{Field Spatial Variability of Soil/Plant Characteristics: Evaluation by Satellite Imagery}

The efficient management of $\mathrm{N}$ in a field with a currently-grown plant requires a recognition of the real status of four variables: (i) the crop's in-season requirement for $\mathrm{N}$, (ii) the spatial variability of the actual $\mathrm{N}$ status in a plant, (iii) the $\mathrm{N}_{\min }$ resources at the onset of the growing season, and (iv) the amount of in-season $\mathrm{N}_{\min }$ released from its soil resources in the rooted soil zone $[10,22]$.

$\mathrm{N}$ management, limited to the current $\mathrm{N}$ plant nutritional status and $\mathrm{N}_{\mathrm{f}}$ input, should be preceded by a field division into zones of homogenous productivity (HFPU) [8]. This is the first step in elaborating an effective soil fertility management system (SFMS). The basis of a particular fertilization system (FS) is data on the current status of the soil organic matter content, soil pH, and content of available nutrients. As reported by Cammarano et al. [23], remote sensing in connection with data on the content of inorganic $\mathrm{N}$ and organic carbon (OC) has been found to be an effective diagnostic tool for the delineation of HFPUs. The first criterion was the Green Normalized Index (GNDVI). This was determined on the basis of a set of 10 years of gathered Landsaft satellite images of wheat at its flowering. The second criterion was the Soil Brightness (SOB), which is based on RapidEye optical satellite images conducted on bare soil. A combination of both spectral indices allowed three or four HFPUs to be delineated. The three-zonal model explained the $\mathrm{N}$ and OC variability the best $(45 \%)$. An indirect evaluation of the soil productivity was possible due to the fact that the wheat canopy at the onset of flowering fairly well reflects its potential productivity (grain density, photosynthetic area). The authors stressed the fact that a field division into three zones fulfills the requirement for the application of the commercial precision agricultural tools.

The in-season recognition of the $\mathrm{N}$ requirements of a currently-grown plant depends on the seed/grain density, but in practice on the number of spikes per unit area $\left(\mathrm{SN}, \mathrm{m}^{2}\right)$ [24]. The most important is, however, the determination of the critical stage of a cereal plant growth with respect to the impact of $\mathrm{SN}$ on the grain yield (GY). As reported by Panek et al. [25], the observed relationship, irrespective of the field location, was the strongest during a period of 4-6 weeks before the onset of wheat or triticale milk maturity. The yield prediction was conducted using seven vegetation indices (VIs), based on satellite images from Sentinel-2. It is worth stressing that yield prediction based on NDVI was a strong yield predictor in the later stages of the growth of both cereals. The rule obtained corroborates the hypothesis that the rate of the cereal crop biomass increase during the shooting phase defines the grain yield [7]. 
The differences in a crop's nutritional status at the stages of its growth which are decisive for yield provides a basis to determine the applied $N_{f}$ rate. The calculated $N_{f}$ dose requires, however, correction, taking into account the spatial variability of a crop's requirement for $\mathrm{N}$. A practical solution aimed at the effective management of $\mathrm{N}_{\mathrm{f}}$ in accordance with a plant's need for $\mathrm{N}$ is to apply the concept of variable-rate nitrogen (VRN). A study, based on 1263 observations by Larson et al. [26] on cotton, showed that the net returns (NRs) increased in response to the applied VRN strategy under well-defined field areas, as determined by higher organic matter content, deeper profiles, or an erodible soil. These three different cases, representing field areas of contrasting productivity, corroborated the necessity for a field's delineation into homogenous productive zones.

\section{Conclusions}

A particular field is a basic unit for crop production. The key challenge for farmers and their advisors is to define and then elaborate a set of agronomic measures oriented towards covering the nitrogen gap. This is the most effective way to realize the 'twin objectives' of sustainable crop production management within a particular field. The spatial variability of yields can be ameliorated, at least, by the division of a field into homogenous productive units. The criteria of a field's division can be based on physical or chemical soil properties, including the whole zone rooted by grown plants. They can also be delineated using satellite spectral images of both bare soil and crop biomass in a well-defined stage, which is decisive for yield component development. The developed agronomic decision support system (ADSS) should be adjusted to the yield potential of the homogenous field unit in order to optimize the efficiency of the applied inputs, mainly focusing on nitrogen fertilizer.

Funding: This research received no external funding.

Conflicts of Interest: The authors declare no conflict of interest.

\section{References}

1. Smith, P. Delivering food security without increasing pressure on land. Glob. Food Secur. 2013, 2, 18-23. [CrossRef]

2. Grzebisz, W.; Łukowiak, R. Nitrogen gap amelioration is a core for sustainable intensification of agriculture-a concept. Agronomy 2021, 11, 419. [CrossRef]

3. Anderson, W.; Johansen, C.; Siddique, H.M. Addressing the yield gap in rainfed crops: A review. Agron. Sustain. Dev. 2016, 26, 18. [CrossRef]

4. Licker, R.; Johnston, M.; Foley, J.A.; Barford, C.; Kucharik, C.J.; Monfreda, C.; Ramankutty, N. Mind the gap: How do climate and agricultural management explain the "yield gap" of croplands around the world? Glob. Ecol. Biogeogr. 2010, 19, 769-782. [CrossRef]

5. Grafton, R.Q.; Williams, J.; Jiang, Q. food and water gaps to 2050: Preliminary results from the global food and water systems (GFWS) platform. Food Secur. 2015, 7, 209-220. [CrossRef]

6. Łukowiak, R.; Grzebisz, W.; Ceglarek, J.; Podolski, A.; Kaźmierowski, C.; Piekarczyk, J. Spatial variability of yield and nitrogen indicators-a crop rotation approach. Agronomy 2020, 10, 1959. [CrossRef]

7. Xie, Q.; Mayes, S.; Sparkes, D.L. Preanthesis biomass accumulation and plant organs defines yield components in wheat. Eur. J. Agron. 2016, 81, 15-26. [CrossRef]

8. Denton, O.A.; Aduramigba-Modupe, V.O.; Ojo, A.O.; Adeoyolanu, O.D.; Are, K.S.; Adelana, A.O.; Oyedele, A.O.; Adetayo, A.O.; Oke, A.O. Assessment of spatial variability and mapping of soil properties for sustainable agricultural production using geographic information system techniques (GIS). Cogent Food Agric. 2017, 3, 1279366. [CrossRef]

9. Gerstmann, H.; Möller, M.; Gläßer, C. Optimization of spectra indices and long-term separability analysis for classification of cereal crops using multi-spectral RapidEye. Int. J. Appl. Earth Obs. 2016, 52, 115-125. [CrossRef]

10. Grzebisz, W.; Łukowiak, R.; Kotnis, K. Evaluation of nitrogen fertilization systems based on the in-season variability in the nitrogenous growth factor and soil fertility factors-a case of winter oilsed rape (Brassica napus L). Agronomy 2020, $10,1701$. [CrossRef]

11. Sulewska, H.; Niewiadomska, A.; Ratajczak, K.; Budka, A.; Panasiewicz, K.; Faligowska, A.; Wolna-Maruwka, A.; Dryjański, L. Changes in Pisum sativum L. plants and in soil as a result of application of selected foliar fertilizers and biostimulators. Agronomy 2021, 11, 1558. [CrossRef]

12. Hlisnikovsky, L.; Menšik, L.; Křížová, K.; Kunzová, E. The effect of farmyard manure and mineral fertilizers on sugar beet beetroot and top yield and soil chemical parameters. Agronomy 2021, 11, 133. [CrossRef]

13. Barłóg, P.; Grzebisz, W.; Pepliński, K.; Szczepaniak, W. Sugar beet response to balanced nitrogen fertilization with phosphorus and potassium. Part I. Dynamics of beet yield development. Bulg. J. Agric. Sci. 2013, 29, 1311-1318. 
14. Massawe, F.; Mayes, S.; Cheng, A. Crop diversity: An unexploited treasure trove for food security. Trends Plant Sci. 2016, 21, 365-368. [CrossRef] [PubMed]

15. Hupe, A.; Schulz, H.; Bruns, C.; Haase, T.; Heß, J.; Joergensen, R.G.; Wichern, F. Even flow? Changes of carbon and nitrogen release from pea roots over time. Plant Soil 2018, 431, 143-157. [CrossRef]

16. Szczepaniak, W.; Grzebisz, W.; Potarzycki, J.; Łukowiak, R.; Przygocka-Cyna, K. Nutritional status of winter oilseed rape in cardinal stages of growth as yield indicator. Plant Soil Environ. 2015, 61, 291-296. [CrossRef]

17. Hlisnikovsky, L.; Menšik, L.; Kunzová, E. The development of winter wheat yield and quality under different fertilizer regimes and soil-climatic conditions in the Czech Republic. Agronomy 2020, 10, 1160. [CrossRef]

18. Wang, X.; Miao, Y.; Dong, R.; Chen, Z.; Kusnierek, K.; Mu, G.; Mulla, D.J. Economic optimal nitrogen rate variability of maize in response to soil and weather conditions: Implications for site-specific nitrogen management. Agronomy 2020, 10, 1237. [CrossRef]

19. Grzebisz, W.; Szczepaniak, W.; Grześ, S. Sources of nutrients for high-yielding winter oilseed rape (Brassica napus L.) during post-flowering growth. Agronomy 2020, 10, 626. [CrossRef]

20. Łukowiak, R.; Grzebisz, W. Effect of site specific nitrogen management on seed nitrogen-a driving factor of winter oilseed rape (Brassica napus L.) yield. Agronomy 2020, 10, 1364. [CrossRef]

21. Olfs, H.-W.; Blankenau, K.; Brentrup, F.; Jasper, J.; Link, A.; Lammel, J. Soil- and plant-based nitrogen-fertilizer recommendations in arable farming. J. Plant Nutr. Soil Sci. 2005, 168, 414-431. [CrossRef]

22. Córdova, C.; Barrera, J.A.; Magna, C. Spatial variation in nitrogen mineralization as a guide for variable application of nitrogen fertilizer to cereal crops. Nutr. Cycl. Agroecosystems 2018, 110, 83-88. [CrossRef]

23. Cammarano, D.; Zha, H.; Wilson, L.; Li, Y.; Batchelor, W.D.; Miao, Y. A remote sensing-based approach to management zone delineation in small scale farming systems. Agronomy 2020, 10, 1767. [CrossRef]

24. Triboi, E.; Triboi-Blondel, A.-M. Productivity and grain or seed composition: A new approach to an old problem-Invited paper. Eur. Agron. J. 2002, 16, 163-186. [CrossRef]

25. Panek, E.; Gozdowski, D.; Stępień, M.; Samborski, S.; Ruciński, D.; Buszke, B. Within-field relationships between satellite-derived vegetation indices, grain yield and spike number of winter wheat and triticale. Agronomy 2020, 10, 1842. [CrossRef]

26. Larson, J.A.; Stefanini, M.; Yin, X.; Boyer, C.N.; Lambert, D.M.; Zhou, X.V.; Tubaña, B.S.; Scharf, P.; Varco, J.J.; Dunn, D.J.; et al. Effects of landscape, soils, and weather on yields, nitrogen use, and profitability with sensor-based variable rate nitrogen management in cotton. Agronomy 2020, 10, 1858. [CrossRef] 